\title{
Nietzsche, immortality, singularity and eternal recurrence $^{1}$
}

\section{Bert Olivier}

\author{
Philosophy \\ NMMU \\ Port Elizabeth \\ South Africa \\ Bert.Olivier@nmmu.ac.za
}

\begin{abstract}
Joan Copjec has shown that modernity is privy to a notion of immortality all its own - one that differs fundamentally from any counterpart entertained in Greek antiquity or the Christian Middle Ages. She points to Blumenberg and Lefort as thinkers who have construed this concept in its modern guise in different ways, and ultimately opts for Lefort's paradoxical understanding of immortality as the 'transcending of time, within time' before elaborating on a corresponding notion in Lacan's work. It can be shown that Nietzsche, too, provides a distinctly modern conception of 'immortality', articulated in relation to his notions of affirmation, singularity and eternal recurrence. In brief, this amounts to his claim that, to affirm even one single part or event in one's life entails affirming it in its entirety, and, in so doing - given the interconnectedness of events - affirming all that has ever existed. Moreover, once anything has existed, it is in a certain sense, for Nietzsche, necessary despite its temporal singularity. Therefore, to be able to rise to the task of affirming certain actions or experiences in one's own life, bestows on it not merely this kind of necessary singularity, but what he thought of as 'eternal recurrence' the (ethical) affirmation of the desire to embrace one's own, and together with it, all of existence 'eternally', over and over. This, it is argued, may be understood as Nietzsche's distinctive contribution to a specifically modern notion of immortality: the ability of an individual to live in such a way that his or her singular 'place' in society is ensured, necessarily there, even after his or her death.
\end{abstract}

In her book, Imagine there's no woman (2002: 19-25), Joan Copjec compares the thought of Lefort and Blumenberg on the topic of immortality in the modern epoch. She remarks quite aptly that the word 'immortalize' - used by Lacan with reference to Antigone - comes across as 'anachronistic' in the modern age (Copjec 2002: 19). Only those who still live as if nothing changed in the transition from the medieval period to the Renaissance (where the battle for the soul of modernity was fought) and from there

1 (C) 2007 Bert Olivier; licensee South African Journal of Philosophy.

This is an open access article distributed under the terms of the Creative Commons Attribution License ("http://creativecommons.org/licenses/by/2.5"), which permits unrestricted use, distribution, and reproduction in any medium, provided the original work is properly cited. 
to the Enlightenment as paradigmatically modern epoch, would find her observation puzzling. It is a truism to say that we live in a thoroughly technocentric, secular era, as opposed to the spirituality (predicated on a belief in eternity) that characterized the theocentric Middle Ages, where a belief in 'immortality' was commonplace. More to the point for my present purposes, however, Copjec (2002: 19-20) continues as follows:

Yet, although one might have expected the notion of immortality to perish completely, to become a casualty of the Enlightenment's secularisation of reason and its dissolution of the links to its past, the truth turns out to be more complex. For, while officially we moderns are committed to the notion of our own mortality, we nevertheless harbor the secret, inarticulable conviction that we are not mortal.

This is a surprising observation, to say the least. She goes on to point to Hans Blumenberg and Claude Lefort, both of whom elaborate on this insight, albeit with different conclusions. What they share, though, is the conviction - evident in the title of Blumenberg's book, The legitimacy of the modern age - that the modern idea of immortality is not merely a religious remnant from a bygone era, '... it is, rather, a new product of the break from our religious past' (Copjec 2002: 20). Copjec (2002: 21) shows that Blumenberg's account of 'modern' immortality is encountered in relation to his claim that, in the modern era, it is unintelligible for an individual to achieve 'complete' knowledge, as the growth or accumulation of knowledge in this age is no longer a function of individual insight or 'intuition', but is linked to 'scientific method' as responsible for the acquisition of 'objective knowledge'. This, together with the sheer rapidity of knowledge production, precludes the individual from being the 'subject of modern knowledge', instead of which one has to turn to a generation of thinkers or scientists to fulfil this function. Blumenberg utilizes Feuerbach's notion of immortality to impart this dimension to his account: for Feuerbach, 'modern' immortality is a function of the difference between the 'knowledge drive' (alternatively, the 'happiness drive') in the human species and its lack of fulfilment in individuals (Copjec 2002: 21). This means that he places the task of pursuing knowledge, which would satisfy the material needs of humanity, on the shoulders of the collective, without alienating individuals from the fruits of this cooperative effort: as individuals they will benefit from the material results of scientific progress, which await them in the future of their mortal lives (Copjec 2002: 22). In this way 'immortality' á la modernity is achieved, for Blumenberg. In Copjec's words (2002: 21):

... once the rapid and conspicuous progress of modern knowledge makes the individual's limited share in this progress unbearable, the notion of immortality arises as a way of healing the wound between the species and the individual, of assuaging the structural dissatisfaction that emerges from their difference.

Lefort's argument is very different, and meets with considerably more approval on Copjec's part than Blumenberg's. Instead of 'replacing' immortality with posterity, as Blumenberg does, Lefort links a 'sense of posterity' with immortality (Copjec 2002: 20-21). With the disappearance of the ancient and medieval belief in eternity (in the sense of timelessness) - according to which, in antiquity, one was thought to participate to some degree in 'everlastingness' through the 'glory' or 'immortality' bestowed on individuals through 'great deeds' - a new sense of 'immortality' becomes possible, 
insofar as the daunting prospect of exchanging time for eternity no longer tantalizes humans. Copjec formulates what is at stake here in exemplary fashion (2002: 20):

The modern notion of immortality benefits from the collapse of our belief in an eternal realm. Where formerly every deed (and the active life, in general) was thought to fail insofar as it was unable to elevate itself out of time, into eternity, in modernity the deed was reconceived as affording one the possibility of transcending historical time within time. This is what is new: this idea that the act could raise itself out of impotence, or out of the immanence of its historical conditions, without raising itself out of time... The valorization of the act helped to forge, Lefort argues, a new link between immortality and 'a sense of posterity'...

It should be added that this connection of immortality with posterity in Lefort's argument is mediated through the concept of 'singularity', in the sense that someone who may be said to attain such 'immortality' in human society does so by clearing a 'place' for her- or himself - '... a place which cannot be taken, which is invulnerable, because it is the place of someone... who, by accepting all that is most singular in his life, refuses to submit to the coordinates of space and time and who... for us... is not dead' (Lefort, quoted in Copjec 2002: 23).

It seems to me that a strong case could be made for the claim that Friedrich Nietzsche preceded Blumenberg, Lefort and $\mathrm{Lacan}^{2}$ as far as the articulation of a distinctly modern - I would prefer to call it a proto-poststructuralist - conception of 'immortality' is concerned - one which is emphatically not a 'remnant' from our religious past, and which, moreover, shares the paradoxical logic that Copjec detects in Lefort's formulation insofar as it is an indication that mortals can 'transcend time within time', in this way 'immortalizing' themselves. It seems to me that Nietzsche's formulation of this paradoxical capacity on the part of humans is encountered - at least in what is arguably a clear, recognizable form - in the context of some of his most difficult ideas, including those of the singularity of the individual, of his exhortation to "become who you are' and the so-called 'eternal return' or (a translation of 'ewige Wiederkehr' that I prefer) 'eternal recurrence'. What one would have to show, then, is that, like Blumenberg and Lefort, he articulates a notion of 'immortality' that is compatible with the modern farewell to the medieval myth of an 'eternal' afterlife, that is, one which elaborates a conception of immortality that would somehow - however paradoxically - show its emergence from and within the very temporality characteristic of being human. In Nietzsche's own terms, it would have to '... remain faithful to the earth' (1984: 125), to the time one is allotted in this life.

At first blush it appears unnecessary to pay lengthy attention to the question whether the doctrine of the 'eternal recurrence' constitutes a cosmological or physical hypothesis, namely that all 'physical' states will recur, exactly as they are at a given time in history, over and over, in perpetuity. Much has been written on it, and the debate will

2 I do not have the space to elaborate here on Lacan's (or Freud's) contribution to the development of the notion of immortality. Copjec (2002: 25-47) does so at length. One could also add the names of thinkers such as Heidegger (1978: 279-311), whose death analysis (according to which no one can take the place of another when it comes to dying) contributes to this modern idea of immortality, Derrida (see 1995: 50-51, e.g.), who elaborates on the notion of responsibility, which '.. demands irreplaceable singularity', and Alain Badiou (2001: 10-12), who argues passionately in favour of the 'immortal singularity' of humans. These are not the only ones whose names could be added to the list of those who concern themselves with the theme addressed here, either. 
probably never be settled conclusively. I am substantially in agreement with Alexander Nehamas (1985: 142-149), that a scrupulous interpretation of the evidence suggests that, fundamentally, Nietzsche's dictum does not have a cosmological or 'physical' meaning, but rather an ethical or existential one. On reflection, however, I believe that what appears to be a formulation on Nietzsche's part, which bears primarily on the successive physical 'states' of the cosmos, may indeed be shown to have an ethical or existential meaning as well, with important implications for the notion of 'immortality' put forward here. ${ }^{3}$ The following formulation from The will to power $(1067 ; 1968$ : 549) is a case in point:

If the world may be thought of as a certain definite quantity of force and as a certain definite number of centers of force - and every other representation remains indefinite and therefore useless - it follows that, in the great dice game of existence, it must pass through a calculable number of combinations. In infinite time, every possible combination would at some time or another be realized; more: it would be realized an infinite number of times. And since between every combination and its next recurrence all other possible combinations would have to take place, and each of these combinations conditions the entire sequence of combinations in the same series, a circular movement of absolutely identical series is thus demonstrated: the world as a circular movement that has already repeated itself infinitely often and plays its game in infinitum.

Judging by face value, this passage may seem to resist ethical-existential interpretation. And yet, if minimal agreement could be reached that the 'quantity of force' that comprises the world includes - as I believe it undeniably must - embodied, in the broadest sense 'energy-driven' individuals, it follows that the 'calculable number of combinations' of all the constituents of Nietzsche's 'world' would bear on the specific configuration and sequence of actions (including moral or ethical actions) performed by these individuals. Even if one grants that such actions, insofar as they are ethical, are not strictly motivated by physical antecedents as 'causes', but by ethical choices or decisions, they would still - as actions performed in time - ineluctably comprise constituents indispensable for the temporal sequence or series of states and events to be the totality that Nietzsche envisages it to be. And if this means, as I believe it does, that every such action would be singular or unique in relation to all the other constituent conditions of the totality, and that, due to its putative infinite repetition, it would have to be re-instantiated, over and over, in the course of infinite time, such actions or, more appositely - the individual agents performing these - may be said to attain a certain 'immortality'.

It may be objected that 'immortality' in this sense is trivial compared to the 'immortality' attributed to specific individuals (under very specific circumstances of agency) by Blumenberg and Lefort, as Copjec has argued, because it seems to apply trivially to every human being who has ever lived (on the supposition that ethical or moral decisions and actions are coterminous with being human). Indeed, I would agree. But at least this much can already be established: human actions of an ethical kind are inseparable from the kind of actions that Nietzsche subsumes under the "calculable number

3 On a previous occasion I put forward such an ethical interpretation of the 'eternal recurrence' (Olivier 1994); here I would like to refine it and relate it to the notion of 'immortality' in the modern age as thematized by Copjec. 
of combinations' that, together, comprise the 'world' as a 'quantity of force'. ${ }^{4}$ And as such they comprise part of the (intermittently) uniquely actualized 'texture' of the fabric of the 'world' that supposedly repeats itself in infinite time. It remains to be shown that, in addition to this 'weak' sense of 'immortality' on the part of morally acting individuals, there is another, strong sense to be found in Nietzsche's work, however one relating to singularity of a more salient kind.

What I wish to argue is that Nietzsche, no less than other representatives of a distinctly 'modern' ethos (such as Blumenberg, Lefort, or, in poststructuralist terms, Lacan), articulates the conditions for 'immortality' in his own, inimitable manner. He does so in relation to (a different aspect of) the doctrine of eternal recurrence and of the singularity of an individual, which is a function of the very specific, creative profile of such an individual against the backdrop of the large, mediocre mass of convention-abiding people in society. To my mind, one possible starting point (among many) - for unpacking this claim - in Nietzsche's work, is a passage in The Will to Power (585A; 1968: 318):

Whoever is incapable of laying his will into things, lacking will and strength, at least lays some meaning into them, i.e., the faith that there is a will in them already.

It is a measure of the degree of strength of will to what extent one can do without meaning in things, to what extent one can endure to live in a meaningless world because one organizes a small portion of it oneself.

In Nietzsche's judgement, most people never get beyond the point where they 'discover' ostensibly inherent, ready-made value(s) in the world into which they are born (Nehamas 1985: 135-136) - they have 'faith' that there is already a 'will' in things. Such people, who would passively bear the values with which tradition, convention or custom burdens them, seem to correspond to the camel or beast of burden in Thus spoke Zarathustra (1984: 138), who would passively bear the values with which tradition, convention or custom burdens them..$^{5}$ The latter (convention) appears to be the counterpart of the dragon on whose scales is written 'Thou shalt', and which has to be overcome by the freedom-conquering spirit, or lion (1984: 138-139), whose conquering activity, in turn, must be presupposed by the playfully creative, self-willing child (1984: 139). ${ }^{6}$ The latter - not by itself, but in conjunction with the two preceding figures - corresponds to those rare people, referred to in the extract, above, who find it tolerable to live in a meaningless world, because they are capable of 'organizing a small portion of it' themselves. It is essentially this kind of person who would exemplify someone capable of attaining 'immortality' in the (new, 'modern') sense, borrowed from Copjec, which I believe one encounters in Nietzsche's thought.

It is important to note that Nietzsche does not advocate a kind of axiological creatio ex nihilo, or bringing forth by fiat of novel values, on the part of those 'free spirits' who manage to prevail creatively in the face of the tremendous force of convention; at

4 For an elaboration on his concept of 'world' in these terms, see Nietzsche (1968: 549-550).

5 Nietzsche asserts that the primacy of convention or custom is fundamental to civilization as such; in The dawn $(16 ; 1984 \mathrm{a}: 76)$ he speaks of '... the relentless compulsion to live up to custom'.

6 It is interesting to compare Nietzsche's metaphor of the innocent, game-playing child (as paradigm of the value-creating person) with Heidegger's (1991: 113) use of the same metaphor to suggest, not the creative individual, but the creative 'play-activity' - perhaps rather 'creative process' - of Being. In so doing, Heidegger divests the metaphor of the 'child at play' of what he understands as an unacceptable anthropocentric (and therefore still metaphysical) dimension. 
best, one can distance oneself from convention by overcoming it in leonine fashion (as suggested by the figure of the lion in Zarathustra), and actively (perhaps playfully) constructing a new set of values for oneself, in this way transforming cultural space. In other words, his requirements concerning 'true individuals' are not tantamount to the impossibility of setting out, at any time, from a cultural tabula rasa. Even if the metaphor of the 'innocent' child may be somewhat misleading, it does not suggest an absolutely new commencement, but - read together with those of the camel and the lion - a prior appropriation and rejection (or, for that matter, transformation) of old values or customs, as the metamorphoses of the camel into the lion, and the latter into the child, suggest. ${ }^{7}$ Nehamas (1985: 225) formulates this dynamic relation between the individual and custom in terms of 'breaking rules':

A true individual is precisely one who is different from the rest of the world, and there is no formula, no set of rules, no code of conduct that can possibly capture in informative terms what it is like to be like that. There are no principles that we can follow in order to become, as Nietzsche wants us to become, unique. On the contrary, it is by breaking rules that such a goal, if it is indeed a goal at all, can ever be reached. And it is as impossible to specify in advance the rules that must be broken for the process to succeed as it is, say, to specify in advance the conventions that must be violated for a new and innovative genre in music or literature to be established. ${ }^{8}$

From the later perspective of Heidegger's thought - strongly influenced, as is well-known, by Nietzsche - these insights on Nietzsche's part may be rearticulated in terms of what Heidegger (in Being and Time) describes as the tripartite, fundamental ontological structure of Dasein, namely thrownness (finding oneself in a given, historical, conventional situation), projection (the inalienable human ability or potential to be one's own 'pro-ject', that is, to design or carve a singular place for oneself in cul-

7 Although Nietzsche's approach is arguably more radically agonistic (struggle-oriented) than Gadamer's in Truth and Method (1982: 238-253), I believe that the latter's stance on the unavoidability of prejudice or pre-judgement as a prerequisite for understanding or interpretive appropriation, is indebted to this aspect of Nietzsche's thought (as well as, of course, Heidegger's notion of 'fore-understanding' in Being and Time [1978: 188-195]). Nehamas (1985: 187) adduces the example of Nietzsche appropriating the traditional concept of 'freedom of the will' for his own 'idiosyncratic... purposes', yielding a new meaning of free will, namely '.. not the absence of causal determination but a harmony among all of a person's preference schemes'. This is not a hermeneutic or epistemological break or hiatus on Nietzsche's part, but an interpretive appropriation of an existing concept.

8 I should point out that, although Nehamas's study has much to recommend it, some commentators do not accept his (or Megill's; see 1985: 29-64) radically aestheticist interpretation of the German philosopher's work. For Nehamas (1985: 229-234) Nietzsche's thought is ultimately to be construed as an aesthetic production of himself in terms of his criteria of coherence among many countervailing forces. That is, Nietzsche is finally understood as that 'magnificent character' who emerges, like the narrator in Proust's Remembrance of Things Past, from the totality of his own texts. In this regard Karsten Harries's remark, a propos of Nehamas's book on Nietzsche, is noteworthy (Harries 1986): 'There is no denying Nietzsche's estheticism, but we must also hear his call for a redemption from the spirit of revenge, a redemption that would overcome every estheticism. We should not forget his sad end when we admire "the magnificent character" emerging through the books he wrote. To trade even a miserable life for the grandest delusion is to strike a questionable bargain'. One could question Harries's use of the word 'delusion' here, however. 
tural space) and falling (the concomitant tendency to succumb to the suffocating pressure of conventional practices). ${ }^{9}$

The degree to which Heidegger's thinking here corresponds to Nietzsche's is more apparent when one remembers that 'projection' means the capacity of individuals - regardless of how seldom it is actualized - to appropriate a given situation, characterized by what Heidegger terms 'everydayness' (cultural and social situations broadly governed by custom, convention, or what is 'fashionable'), and transform it creatively. This could happen by the individual seizing every possible opportunity to actualize one's own, distinctive 'project', even if the tendency to 'fall' back into the comfort zone of tradition and convention always exercises its gravitational pull on them. Like Nietzsche before him, Heidegger is acutely aware of the ubiquity of axiological-cultural conservatism or inertia. ${ }^{10}$

Although necessary, 'breaking' cultural (artistic, literary, philosophical, political) 'rules' is not sufficient for a person to emerge from the ranks of the conventional masses as a distinctive, 'immortal' individual. What else is required, according to Nietzsche? It seems to me that his difficult notion, 'Become who you are' (which is encountered throughout his work; see Nehamas (1985: 171-172), and which is related to the notion of the singularity of an individual or 'free spirit', points in the direction of one such requirement. Not only is Nietzsche's intellectual autobiography, Ecce Homo (1979; written in 1888), subtitled 'How one becomes what one is', ${ }^{11}$ but the idea appeared in his thought as early as 1874 (Nehamas 1985: 171), and could be seen as a leitmotiv in Thus spoke Zarathustra (1984: 351; written in the early to middle 1880s).

9 Heidegger formulates the relationship between the individual and tradition or convention (that is, the relationship between thrownness, projection and falling) in terms of 'care' (1978: 458):

Dasein exists as an entity for which, in its Being, that Being is itself an issue. Essentially ahead of itself, it has projected itself upon its potentiality-for-Being before going on to any mere consideration of itself. In its projection it reveals itself as something which has been thrown. It has been thrownly abandoned to the 'world,' and falls into it concernfully. As care - that is, as existing in the unity of the projection which has been fallingly thrown - this entity has been disclosed as a 'there.'

10 In similar vein, one could cite Lacan's claim, that (1997, pp. 21-22): ' $\ldots$ the ethical limits of psychoanalysis coincide with the limits of its practice. Its practice is only a preliminary to moral action as such... ' What he describes as 'assuming one's desire' (with the help of psychoanalysis) is only a preparation for possible ethical action on the part of the client, and a condition for it, because such 'taking up' of one's uniquely personal 'desire' - which is irreducibly singular for each person (Lacan, 1997: 24) - would invariably have the character of a transgression of conventional (that is, conventionally sanctioned) morality. It is striking that, the differences in idiom notwithstanding, Nietzsche preceded Lacan to a remarkable degree by putting forward an axiological argument in favour of the 'free spirit' transgressing the confines of conventional practices, including moral ones (see Olivier 2005 in this regard). Because it is difficult to give 'positive content' to such transgressive action, it is at least partly understandable that, as Nehamas (1985: 221-222) points out, Nietzsche's 'positive' views on morality are banal and vague, among other things. The frequency with which he speaks approvingly of 'evil', however, has to be seen in the same light as 'transgressive action' in the sense specified here. In The Gay Science (1984b: 93), for instance, he says: 'The new is always the evil, as that which wants to conquer, to overthrow the old boundary stones and the old pieties; and only the old is the good... But all land is finally exhausted, and the plow of evil must always return'. Clearly, 'the old' means (or at least includes) custom, convention, or tradition, here.

11 To anyone familiar with Kierkegaard this may ring a bell - the one attached to Kierkegaard's so-called 'ethical' model of existence, according to which one should live in such a way that one continually and increasingly makes one's life into an integrated or unified 'work of art' (Kierkegaard 1971: 141; Melchert 1991: 434; see also Olivier 2005a). 
"Becoming who one is" is related to the question of the 'unity' or integrity of the self in Nietzsche's thought. Nehamas puts it succinctly (1985: 182): "The unity of the self, which... also constitutes its identity, is not something given but something achieved, not a beginning but a goal." In other words, for Nietzsche there is no question of a unity at the outset of the individual's life; at any given time, there are at best a multiplicity of countervailing tendencies and forces at work in every human being. Nor is the goal of being a unified self ever conclusively achieved; even if it is actualized at any given time, this does not preclude the necessity of continuing with the arduous business of fusing new experiences or developments 'apperceptively' with what has gone before (Nehamas, 1985: 185). The task facing everyone is to harness all those conflicting forces (strengths as well as flaws) and experiences (joys as well as sufferings) in such a manner that they conspire together to give coherence to the person's life - a task that is never really complete, and has to be actively carried out in a sustained way, more or less all the time. What makes a true or 'singular' individual, for Nietzsche, is precisely the ability to overcome the tendency towards a kind of disintegration of the self into incompatible components, reneging on the (admittedly formidable) effort to refuse and conquer this tendency. Such a refusal manifests itself in harnessing all the divergent traits and characteristics that comprise a personality, artfully coordinating their differences towards the goal of being an integrated, self-creating, self-created person. In The Gay Science Nietzsche depicts it as follows (290; 1984b: 98-99):

One thing is needful. 'Giving style' to one's character - a great and rare art! It is exercised by those who see all the strengths and weaknesses of their own natures and then comprehend them in an artistic plan until everything appears as art and reason and even weakness delights the eye. Here a large mass of second nature has been added; there a piece of original nature has been removed: both by long practice and daily labor. Here the ugly which could not be removed is hidden; there it has been reinterpreted and made sublime... It will be the strong and domineering natures who enjoy their finest gaiety in such compulsion, in such constraint and perfection under a law of their own...

More succinctly, with an historical slant, he says (in The Will to Power 1014; 1968: 524): 'It is only a question of strength: to have all the morbid traits of the century, but to balance them through a superabundant, recuperative strength'. It would appear that Goethe exemplified, for Nietzsche, this rare kind of individual: 'Goethe', he says in The Will to Power $(95 ; 1968: 60)$ '... seeks to form a totality out of himself, in the faith that only in the totality everything redeems itself that appears good and justified'. And elsewhere (in Twilight of the Idols; 1984c: 554), he claims that Goethe '... fought the mutual extraneousness of reason, senses, feeling, and will... he disciplined himself to wholeness, he created himself.' In the language of the present hypothesis, Goethe, for Nietzsche, is 'immortal'.

If indeed the specific 'traits' of an historical era could be said to be condensed in a person, what role does historical contingency - that is, chance - play in shaping a person into a distinctive individual? And if it does in fact play an important part - as Nehamas implies where he says of Nietzsche's idea of self-creation (1985: 188) '... that everything that we have done actually constitutes who each one of us is' - how could such contingency possibly rhyme with the thought of the 'eternal recurrence'?

First, one should note what Nietzsche says about duration 'in vain' (nihilism, or the 
absence of a persuasive sense of axiological teleology) in The Will to Power (55; 1968: 35): 'Let us think this thought in its most terrible form: existence as it is, without meaning or aim, yet recurring inevitably without any finale of nothingness: "the eternal recurrence". This clearly emphasizes the contingency, as opposed to the teleologically orchestrated necessity of existence. And the axiological - but also the ethical and existential - problem that this poses is that of possibly inescapable, radical nihilism, that is, the realization of the utter contingency, as well as the meaninglessness of everything (see Nietzsche 1968 [I; 3]: 9) At the same time this very realization poses the ethical or existential task facing every individual, the acceptance (affirmation) or negation of which determines whether one is finally capable of 'creating oneself' as a true, axiologically active individual. That it is an extremely difficult affirmation to make leaves no doubt, as Zarathustra's difficulty demonstrates (see for example Nietzsche, 1984: 250-253). And yet to be able to transform the utter contingency of one's personal existence into something 'necessary' (in a non-teleological sense), and to redeem such contingency ethically and axiologically, one has to embrace it in all its variegatedness - affirming it unconditionally, willing its endless repetition or recurrence ${ }^{12}$ and, moreover, learn to love it (Nietzsche 1979: 68): 'My formula for greatness in a human being is amor fati: that one wants nothing to be other than it is, not in the future, not in the past, not in all eternity'. But then he adds something ostensibly contradictory: 'Not merely to endure that which happens of necessity, still less to dissemble it... but to love it...'

This - enduring, even loving, what occurs 'of necessity' - would indeed be problematical if one understands Nietzsche's use of the term, 'necessity', as being incompatible with him as someone who, in his work, affirms the earth, this inescapably temporal or historical human life with all its sometimes unbearable contingency, which one has to learn to embrace, ${ }^{13}$ thus becoming 'overhumans' (to coin a term). And yet, it is precisely here that his contribution to a 'modern' notion of 'immortality' may be discerned. Deleuze helps one to understand this where he remarks, a propos of chance or contingency in Nietzsche's thought (1983: 26):

... just as unity does not suppress or deny multiplicity, necessity does not suppress or abolish chance. Nietzsche identifies chance with multiplicity, with fragments, with parts, with chaos: the chaos of the dice that are shaken and then thrown. Nietzsche turns chance into an affirmation... What Nietzsche calls necessity (destiny) is... never the abolition but rather the combination of chance itself. Necessity is affirmed of chance in as much as chance itself [is?] affirmed. [Sic.]

It is no accident that, as Deleuze (1983: 26) points out, the idea of chance is pervasive in Zarathustra's narrative. After all, it is in this text (1984: 278) that Nietzsche attempts (via Zarathustra) to 'release' everything under the sun from the servitude to an overarching teleology, because things (and this would include humans) '...would rather

12 It should be clear from what I have said about the connection between affirmation and the 'eternal recurrence', that I disagree strongly with Allan Megill (1985: 83-84), who believes that it is virtually impossible to arrive at a cogent interpretation of the doctrine (the 'eternal recurrence' or 'eternal return').

13 An exemplary Nietzschean ('actively nihilistic') cinematic celebration of the value of contingency in human earthly life is encountered in Wim Wenders's exhilarating film, Wings of Desire (Himmel über Berlin), where Wenders uses the figure of an angel who, despite the apparent advantages of his own timeless angelic 'existence', chooses to 'fall into' human time and history, to be able to experience the pleasure of contingent events such as drinking a cup of coffee. See Olivier (1992) in this regard. 
dance on the feet of Chance'. The point is that the 'impossible' strength to affirm the chance events in life - 'impossible' because sometimes this would include affirming devastating, contingent events such as losing one's sight, or one's physical ability to move in what is properly called an 'accident', or unexpectedly contracting the HI virus - bestowing on contingency a certain necessity or 'destiny', is what activates the 'eternal recurrence'. Once affirmed in this way, the contingent, the arbitrary, is tied into the circle of necessity, of the 'eternal recurrence'. And the rare individual who is able to do this, to rise to such unconditional acceptance of her or his finitude (our inability to undo what has happened once), of her or his mortality - in this way overcoming what Nietzsche, in the persona of Zarathustra (1984: 252), calls the 'spirit of revenge': '... the will's ill will against time and its "it was" - lays the foundation for paradoxically attaining 'immortality', for surpassing the bounds of time and (human) history within time and history. Such a person would also attain 'singularity' in so far as it is linked with the affirmation of the unique, though contingent, actions performed by an individual, in this way imparting 'necessity' to them.

Is it at all surprising to find in this an echo of Lefort's notion of 'singularity', discussed by Copjec in relation to 'modern immortality'? Her clarification of the concept of singularity (as opposed to particularity, associated with what is fleeting and does not endure) is worth quoting at length (Copjec, 2002: 23-24):

This notion of singularity, which is tied to the act of a subject, is defined as modern because it depends on the denigration of any notion of a prior or superior instance that might prescribe or guarantee the act. Soul, eternity, absolute or patriarchal power, all these notions have to be destroyed before an act can be viewed as unique and as capable of stamping itself with its own necessity. One calls singular that which, 'once it has come into being, bears the strange hallmark of something that must be,' and therefore cannot die...

Is there not a striking consonance between Lefort's words, quoted by Copjec towards the end of this excerpt, and what was outlined earlier concerning the connection between contingency and necessity in Nietzsche's thought, in so far as it bears on singularity (and therefore immortality of the modern sort)? ${ }^{14}$

It would be remiss on my part to omit a brief reference to some of Nietzsche's remarks on the 'free spirit' in Beyond Good and Evil (1966), given the (not unambiguous) light that these observations cast on the question of singularity and 'modern immortality'. Consider the following such remark, for instance (1966: 37):

Every choice human being strives instinctively for a citadel and a secrecy where he is saved from the crowd, the many, the great majority - where he may forget 'men who are the rule,' being their exception - excepting only the one case where he is pushed straight to such men by a still stronger instinct, as a seeker after knowledge in the great and exceptional sense.

Nietzsche's conception of the 'free spirit' as exceptional and distinctive is apparent in

14 Admittedly, it seems ironic to make this statement, considering that Copjec includes 'patriarchal power' among those things, the destruction of which are a prerequisite for an 'act' to be affirmed as being unique, if Nietzsche's own arguable inability to free himself from the hold of patriarchy is remembered. Nevertheless, I believe that, despite this, one could indeed discern in his thought the lineaments of actions being unique or singular. This could be shown to have paved the way for the demise of patriarchy, to the extent that it created receptivity for such actions on the part of women by articulating the conditions of comprehensibility of singularity. 
the first part of this excerpt, but what is one to make of his allusion to those instances where these unusual individuals, as seekers after 'exceptional knowledge', are drawn to the 'mediocre majority'? His further reference to the free spirit's (possible) exclamation, that "the rule is more interesting than the exception - than myself, the exception!"', followed immediately by the sentence 'And he would go down, and above all, he would go "inside"" (Nietzsche 1966: 37), provides an important clue as to how one should understand him here. After all, this remark echoes Zarathustra, in the Prologue, who decides to go 'down' to the people, because he 'loves' them, with Nietzsche (1984: 121-123) drawing an analogy between Zarathustra and the sun insofar as a 'giver' - whether it be the sun, brimming with light and warmth, or Zarathustra, overflowing with wisdom - has a need for those who would receive his or her (or its) 'gift'.

Add to this the elaboration, in Beyond Good and Evil (1966: 35), on the 'will to knowledge' as being underpinned by a more profound 'will to ignorance' 15 - with Nietzsche stressing that these are not opposites, but 'degrees' or 'gradations' of the same thing - then it would seem to me that, for Nietzsche, even the exceptional individual can only be truly such when not seen in isolation, but in close proximity to, and even complex intertwinement with, the encompassing community - who needs the wisdom imparted by the free spirit, and who is, simultaneously, needed by the latter for his or her 'completion', in a sense.

In short: the singularity of the 'free spirit' can only become clearly apparent, not in splendid isolation, but in relation to those from whom he or she differs - with all the risks and dangers attendant upon such a relation, as Plato, in The Republic (Book VII, 516-518; 1991: 195-196) already suggested in the myth of the cave by intimating that, returning to the community of cave-dwellers with news of the sun illuminating the outside world, poses grave risks for the newsbearer, who is likely to be incomprehensible (and therefore ostensibly mad) to those who live in darkness. 'Exceptional knowledge' can therefore only be attained in this more encompassing context, and one is struck by the ambiguity of the term, 'knowledge', as used by Nietzsche - sometimes to denote what people erroneously regard as stable, conclusive, unshakeable 'science', unaware of its mendaciousness, and sometimes - as in the case of the 'great' knowledge, attainable by the free spirit when he or she decides to 'go down' to the people - as 'knowledge' that is reflectively aware of its artificial, constructed, provisional, revisable status (Nietzsche 1966: 35-36).

While the free spirit is afforded greater knowledge in proximity to other people, however, the opposite is apparently not true (Nietzsche 1966: 51):

Every profound spirit needs a mask: even more, around every profound spirit a mask is growing continually, owing to the constantly false, namely shallow, interpretation of every word, every step, every sign of life he gives... ${ }^{16}$

In other words, the 'place' of the 'free spirit' in society is marked, perhaps only visibly or perceptibly in retrospect, by the 'mask(s)' that he or she may be seen to be wearing

15 Here, again, Nietzsche may be seen as preceding a later thinker in a crucial respect; his 'will to untruth' or 'ignorance' anticipates Lacan's (1977: 3) assertion, that human knowledge has a 'paranoiac' structure. Lacan does develop the notion further, of course, in the context of his poststructuralist psychoanalytic theory (see in this regard Olivier 2004a).

16 This passage demonstrates Nietzsche's hermeneutic acuity: he is quite aware of the role of prejudice or pre-judgement in all acts of interpretation (see note 7) - people who do not share the same 'framework' of pre-understanding as another (especially of someone who has gone out of his or her way to construct 
in comparison to those around them (who may seem not to be wearing such masks. This 'singular place' - which cannot be occupied by anyone else, and therefore stands out as something that resists the flow of time, making these individuals 'irreplaceable', or 'immortal' - is only discernible in relation to the encompassing fabric of a community or society. Moreover, as Copjec (2002: 23-24) emphasises, such 'immortal', irreplaceable 'places' are indispensable for the social bond to be constituted in the face of the flux of time.

It seems to me that these insights from Beyond Good and Evil reinforce my contention, that one encounters in Nietzsche a distinctive version of what Copjec, in her examination of Lefort, Blumenberg and other thinkers, terms a 'modern' notion of 'immortality'. Much more could be added, of course, to all that has been said, though, to render this notion more cogent in the thought of Nietzsche. For present purposes, one could summarize by saying that, for Nietzsche, 'immortality' requires not merely that one is capable of transcending custom and convention innovatively in the process of 'creating oneself' or 'becoming who you are'. One should also be able to affirm the contingent actions and 'chance' experiences and events accompanying such an axiologically creative mode of living, as if these experiences would recur infinitely, that is, eternally (that is, willing them to recur in this fashion; see Nehamas, 1985: 232), in this way imparting 'necessity' to them and to one's life. The 'singularity' of an individual, inaugurated in this way, opens up a space of inimitable proportions, a place not occupiable by anyone else, and therefore immortalizes the person in question.

I am well aware that not everyone would agree with this assessment of Nietzsche's thought. Agreement or disagreement hinges, it appears, ${ }^{17}$ on whether readers find the evidence that I have adduced in support of the claim that there is, for Nietzsche, a hermeneutically reciprocal relation between the 'free spirit' (the exceptional individual) and the rest of society, convincing. This means that, unless the exceptional, creative individual's 'works' are 'received' by his or her public in an interpretive-hermeneutic manner that testifies to their confirmation of its cultural significance - regardless of interpretive differences among members of such an audience or public - the singularity of the individual in question, and hence his or her 'immortality', would be unthinkable. In other words, not merely inventiveness or originality ('breaking the rules') is required in relation to existing convention; the stamp of society on innovation or inventiveness as such - something that presupposes the interpretability of the inventive work in question - is also necessary for it to constitute a claim to irreplaceability, immortality, on the part of the exceptional individual (see Hurst, 2005: 163-170 in this regard).

Apart from what I said earlier to substantiate the claim that Nietzsche's thinking on the topic satisfies these requirements, I shall point to only one more passage, which I believe provides important further textual evidence to this effect. The passage in question comes from Thus spoke Zarathustra (III, 'The convalescent'; 2), where a conversation between Zarathustra and his animals takes place. In the course of this conversation his animals (the eagle and the serpent) say to him (1984: 332): "For your animals

less popular, and to varying degrees more esoteric, 'frameworks' for understanding the world), could be said to judge the 'profound spirit', ineluctably, by something that 'masks' what they 'truly' are. The more radical upshot of Nietzsche's remark is, of course, that it is questionable whether the 'true' nature or character of the free spirit - or, for that matter, of the 'masses' - is, in his terms, ever accessible, instead of which one always only encounters masks upon masks.

17 This was pointed out to me by my philosophical colleague and best, if severest, critic, namely Andrea Hurst. 
know well, O Zarathustra, who you are and must become: behold, you are the teacher of the eternal recurrence - that is your destiny!" Here, as in the other words that they address to Zarathustra in this section, the animals act as an audience or constituency for Zarathustra, showing that, of all the living beings addressed in this narrative, they are the only ones who may truly be said to understand what he teaches. This may seem trivial to some - what are animals, compared to humans, as far as comprising an audience or 'public' is concerned? But if one keeps in mind that all the figures invented in this text have interrelated symbolic meanings and significance, it is not inconsequential that the animals have understood him (even if, judging by Zarathustra's responses in this section, they may be seen as 'echoing' him to a certain degree), in this way confirming his distinctive cultural (prophetic, educational) function. After all, if Zarathustra is at pains to bring humans the news that they must learn to love the earth because God is dead, it is hardly surprising that beings that are close to the earth, without any religious or metaphysical illusions - animals - are the ones who 'show understanding' in this narrative, in contrast to the people he addresses (even the 'higher men', who show glimpses of understanding from time to time, then regress in this respect).

I would suggest, then, that his listening, talking 'animals' may be read as metaphorically representing receptive human beings who are attuned to the message that Nietzsche is bringing via the figure of Zarathustra. By using the figure of 'animals' Nietzsche intimates that an important prerequisite for 'understanding' him is to remember that humans are animals of a certain type, who have largely forgotten that they are such, and therefore tend to neglect or disregard those attributes ('instincts', drives, and so on) which they share with 'real' animals, and that connect them with the earth. Beings such as 'real' animals have no choice in the matter; they live instinctively in accordance with the Dionysian cycle of birth, growth, decay and resurrection (of the species). The important point that this section illustrates, I believe, is that Nietzsche is not completely sceptical (or pessimistic) - as he sometimes appears - about the prospects of having an 'audience' or public that would confirm his creative, inventive contribution to philosophy, and therefore to culture. ${ }^{18}$

I conclude this paper with an excerpt from The Will to Power (1032; 1968: 532-533) which captures, succinctly (if implicitly), much of what I have argued:

If we affirm one single moment, we thus affirm not only ourselves but all existence. For nothing is self-sufficient, neither in us ourselves nor in things; and if our soul has trembled with happiness and sounded like a harp string just once, all eternity was needed to produce this one event - and in this single moment of affirmation all eternity was called good, redeemed, justified, and affirmed. ${ }^{19}$

18 One final observation on this issue: the very fact that Nietzsche wrote in an extant language, and went to certain undeniable lengths to have his writings published, is a performative confirmation of his desire for, and implicit belief in the possibility of, an audience, readership or interpretive community.

19 Compare this passage with a formulation of the same thought in 'The drunken song' (10,

Part 4; 1984: 435), in Thus spoke Zarathustra. Needless to say, in Nietzsche's use of the term 'eternity', its meaning differs fundamentally from that which it bears in antiquity and the middle ages, namely 'timelessness' or the absence of time - this much should be evident already from Copjec's discussion of immortality, addressed at the beginning of this paper. For Nietzsche, by contrast with the ancient and 


\section{References}

Badiou, A. 2001. Ethics. An essay on the understanding of evil. P. Hallward, trans. New York: Verso.

Copjec, J. 2002. Imagine there's no woman. Cambridge, Mass.: The MIT Press.

Deleuze, G. 1983. Nietzsche and philosophy. H. Tomlinson, trans. New York: Columbia University Press.

Derrida, J. 1995. The gift of death. D. Wills, trans. Chicago: The University of Chicago Press.

Gadamer, H-G. 1982. Truth and method. G. Barden \& J. Cumming, trans. \& ed. New York: Crossroad.

Harries, K. 1986. 'The world as a work of art', New York Times Review of Books, 19 January.

Heidegger, M. 1978. Being and time. J. Macquarrie and E. Robinson, trans. Oxford: Basil Blackwell.

Heidegger, M. 1991. The principle of reason. R. Lilly, trans. Bloomington: Indiana University Press.

Hurst, A. 2005. 'Derrida's quasi-transcendental interweaving of invention and interpretation. International Review of the Aesthetics and Sociology of Music 36(1), 159-178.

Kierkegaard, S. 1971. Either/or. Vol. II, W. Lowrie, trans. Princeton, N.J.: Princeton University Press.

Lacan, J. 1977. 'The mirror stage as formative of the function of the I as revealed in psychoanalytic experience', Écrits: A selection, A. Sheridan, trans. New York: W.W. Norton, pp. 1-7.

Lacan, J. 1997. The seminar of Jacques Lacan - Book VII: The ethics of psychoanalysis 1959-1960, D. Porter, trans. New York: W.W. Norton.

Megill, A. 1985. Prophets of extremity. Nietzsche, Heidegger, Foucault, Derrida. Berkeley: University of California Press.

Melchert, N. 1991. The great conversation. A historical introduction to philosophy. London: Mayfield Publishing Company.

Nehamas, A. 1985. Nietzsche: Life as Literature. Cambridge, MA: Harvard University Press.

Nietzsche, F. 1966. Beyond good and evil: prelude to a philosophy of the future. Walter Kaufmann, trans. New York: Vintage Books.

Nietzsche, F. 1968. The Will to Power. Walter Kaufmann \& R. J. Hollingdale, trans. New York: Vintage Books.

Nietzsche, F. 1979. Ecce Homo. How one becomes what one is. R. J. Hollingdale, trans. Middlesex: Penguin Books.

Nietzsche, F. 1984. Thus spoke Zarathustra. in The portable Nietzsche. Walter Kaufmann, trans. \& ed. New York: Penguin Books, 103-439. 
Nietzsche, F. 1984a. From: The Dawn, in The portable Nietzsche. Walter Kaufmann, trans. \& ed. New York: Penguin Books, 76-92.

Nietzsche, F. 1984b. From: The Gay Science, in The portable Nietzsche. Walter Kaufmann, trans. \& ed. New York: Penguin Books, 93-102.

Nietzsche, F. 1984c. Twilight of the Idols, in The portable Nietzsche. Walter Kaufmann, trans. \& ed. New York: Penguin Books, 463-563.

Olivier, B. 1992. 'Postmodern cinema and postmodern culture: information-communication, otherness and history in Wenders's Himmel über Berlin (Wings of Desire)', Literator 13,(3). 1-12 (Special edition on Film and Theory). Reprinted in Olivier, B. 2002. Projections: Philosophical themes on film. University of Port Elizabeth Publications. Second, enlarged edition, 79-94.

Olivier, B. 1994. 'Nietzsche en die 20ste-eeuse denke' (Nietzsche and 20 th -century thought), Wysgerige Perspektiewe op die 20ste eeu. D.F.M. Strauss, ed. Bloemfontein: Tekskor, 56-71.

Olivier, B. 2004. '"Passive" nihilism in Clark's Kids and Hardwicke's Thirteen'. South African Journal of Art History 19, pp. 98-109.

Olivier, B. 2004a. 'Lacan's subject: the imaginary, language, the real and philosophy'. South African Journal of Philosophy, Vol. 23 (1), 1-19.

Olivier, B. 2005. 'Lacan and the question of the psychotherapist's ethical orientation'. South African Journal of Psychology, 35 (4), 657-683.

Olivier, B. 2005a. 'Beyond Kierkegaard's aesthetic and ethical models as paradigms of art'. South African Journal of Art History 20, 176-187.

Plato. 1991. The Republic of Plato. Second Edition. A. Bloom, trans \& ed. Basic Books. 